\title{
HUBUNGAN TINGKAT PENGETAHUAN DENGAN PERILAKU HIDUP BERSIH DAN SEHAT (PHBS) RUMAH TANGGA DI DESA BANJARSARI KULON KABUPATEN BANYUMAS TAHUN 2017
}

\author{
Karina Widyastuti $^{*}$, Nur Hilal ${ }^{* *}$ ) \\ Jurusan Kesehatan Lingkungan, Politeknik Kesehatan Kemenkes Semarang, \\ Jl.Raya Baturaden KM 12 Purwokerto, Indonesia
}

\begin{abstract}
Abstrak
Perilaku Hidup Bersih dan Sehat (PHBS) adalah semua perilaku kesehatan yang dilakukan atas kesadaran sehingga anggota keluarga atau keluarga dapat menolong dirinya sendiri di bidang kesehatan dan berperan aktif dalam kegiatan-kegiatan kesehatan di masyarakat. Penelitian bertujuan untuk mengetahui adanya hubungan antara tingkat pengetahuan dengan PHBS rumah tangga pada masyarakat di Desa Banjarsari Kulon. Metode yang digunakan dalam penelitian ini adalah penelitian obsevasional analitik dengan pendekatan cross sectional. Penelitian dilakukan melalui pengumpulan data primer dari masyarakat desa Banjarsari Kulon dan pengumpulan data sekunder dari Dinas Kesehatan Kabupaten Banyumas dan Puskesmas. Berdasarkan hasil penelitian tentang hubungan antara tingkat pengetahuan dengan perilaku hidup bersih dan sehat (PHBS) rumah tangga di desa Banjarsari Kulon menunjukkan ada hubungan antara tingkat pengetahuan dan praktik PHBS di Desa Banjarsari Kulon. Ditunjukkan dengan signifikan 0,000 dengan arah hubungan positif sebesar 0,421 sehingga menunjukkan hubungan sedang antara tingkat pengetahuan dengan praktik PHBS rumah tangga. Disimpulkan ada hubungan antara tingkat pengetahuan dan praktik PHBS di Desa Banjarsari Kulon, Kecamatan Sumbang, Kabupaten Banyumas, yaitu ada hubungan positif antara tingkat pengetahuan responden dengan praktik PHBS rumah tangga.
\end{abstract}

Kata kunci: kesehatan lingkungan; pengetahuan; praktik; perilaku hidup bersih dan sehat

\begin{abstract}
The Relationship between Level of Knowledge and Behavior of Living Clean and Healthy Households in Banjarsari Kulon Village, Banyumas District year 2017. Clean and healthy behaviors is all this behavior health done at of consciousness resulting family members or the family would help themselves in the health and play an active role in health activities in the community. The research aims to understand the connection between the level of knowledge by clean and healthy behaviors households in the Banjarsari Kulon. The methodology that was used in this research was observational research analytic with the approach cross sectional. The research was done through the collection of primary data of Banjarsari Kulon villagers and collecting secondary data from the office of district health and community health centers Banyumas district. Based on the research done about the relationship between the knowledge with clean and healthy behaviors households in Banjarsari Kulon there was a correlation between the knowledge and practices clean and healthy behaviors in Banjarsari Kulon village. Indicated by significant 0,000 to the direction of a positive relationship of 0,421. Concluded there was a correlation between the level of knowledge and the practices of clean and healthy behaviors in Banjarsari Kulon village, which is there are a positive correlation between the level of knowledge was with the practices of clean and healthy behaviors households.
\end{abstract}

Keywords: environmenthal health; knowledge; practice; clean and healthy behaviors 


\section{Pendahuluan}

Henry L. Blum (1974), seperti yang dikutip Azwar (1983) menggambarkan faktor-faktor yang mempengaruhi kesehatan berdasarkan besarnya pengaruh meliputi secara berurutan, faktor lingkungan, faktor perilaku, faktor pelayanan kesehatan, faktor dan faktor keturunan. Keempat faktor tersebut di samping berpengaruh langsung terhadap kesehatan, juga saling berpengaruh satu sama lainnya. Status kesehatan akan optimal jika keempat faktor tersebut secara bersamasama dalam kondisi optimal pula. Jika satu faktor terganggu (tidak optimal), status kesehatan akan bergeser ke arah bawah optimal. Dengan kata lain, intervensi dalam upaya memelihara dan meningkatkan kesehatan, harus ditujukan pada keempat faktor tersebut. (Promosi Kesehatan, h. 8, 2012)

Upaya kesehatan merupakan serangkaian kegiatan yang dilakukan secara terpadu, terintregasi, dan berkesinambungan untuk memelihara dan meningkatkan derajat kesehatan masyarakat dalam bentuk pencegahan penyakit, peningkatan kesehatan, pengobatan penyakit dan pemulihan kesehatan oleh pemerintah dan oleh masyarakat. Pasal 47 Undang-Undang No. 36 tahun 2009 tentang kesehatan mengatakan, upaya kesehatan tersebut diselenggarakan dalam bentuk kegiatan dengan pendekatan promotif, preventif, kuratif, dan rehabilitatif yang dilaksanakan secara terpadu, menyeluruh, dan berkesinambungan. (UU Nomor 36 pasal 47 tentang Upaya Kesehatan)

Menurut WHO pada data terakhir tahun 2011, setiap tahunnya sekitar 2,2 juta orang di negara-negara berkembang terutama anak-anak meninggal dunia akibat berbagai penyakit yang disebabkan oleh kurangya air minum yang aman, sanitasi dan hygiene yang buruk. Terdapat bukti bahwa pelayanan sanitasi yang memadai, persediaan air yang aman, sistem pembuangan sampah serta pendidikan hygiene dapat menekan angka kematian akibat diare sampai 65\%, serta penyakit-penyakit lainnya sebanyak 26\%. Berdasarkan data diatas dapat dikatan bahwa peran PHBS dalam dasar ilmu kesehatan sangat berperan penting dalam menanggulangi penyakitpenyakit yang dapat timbul dikemudian hari oleh karenanya peran pemerintah, petugas-petugas kesehatan dan masyarakat untuk lebih berperan dan proaktif dalam mengimplementasikan dan melaksanankan strategi PHBS di berbagai tatanan rumah tangga, sekolah, tempat kerja, sarana kesehatan dan tempat-tempat umum, untuk kesehatan masyarakat yang lebih sehat. (WHO, 2011)

Berdasarkan data hasil kajian PHBS Tatanan Rumah Tangga yang dilaporkan oleh Dinas Kesehatan Kabupaten/Kota di Jawa Tengah tahun 2015 persentase rumah tangga yang dipantau sebesar $46,45 \%$, menurun bila dibandingkan tahun 2014, yaitu 49,99\%. Rumah tangga sehat, yaitu yang diwakili oleh rumah tangga

\footnotetext{
${ }^{*}$ E-mail: karinawidya13@gmail.com

${ }^{* *}$ E-mail: inung.nh@gmail.com
}

yang mencapai strata sehat utama dan sehat paripurna tahun 2015 telah mencapai 76,73\%, meningkat bila dibandingkan capain tahun 2014 yaitu 71,46 \%. Persentase rumah tangga ber-PHBS tahun 2015, sedikit lebih tinggi dari target Renstra yaitu $76 \%$. Perubahan perilaku tidak dapat terjadi dalam waktu singkat, tetapi memerlukan proses yang panjang termasuk didalamnya perlu upaya pemberdayaan masyarakat yang berkesinambungan. Terdapat 23 kabupaten/kota dengan persentase rumah tangga sehat melebihi target Renstra. Kabupaten/kota dengan persentase rumah tangga sehat tertinggi adalah Klaten yaitu 96,43 \%, diikuti Kota Magelang 95,93 \%, dan Kota Surakarta 94,71 \%. Kabupaten/kota dengan persentase rumah tangga sehat terrendah adalah Brebes yaitu 55,89 persen, diikuti Kendal 59,87 \%, dan Kudus 62,28 \%. (Profil Kesehatan Provinsi Jawa Tengah Tahun 2015)

Keluarga mempunyai peran penting dalam meningkatkan kualitas kesehatan masyarakat, karena di dalam keluarga terjadi komunikasi dan interaksi antara anggota keluarga yang menjadi awal penting dari suatu proses pendidikan perilaku. Tatanan rumah tangga di Kabupaten Banyumas yang ber-PHBS Tahun 2015, sejumlah 205711 (79,4\%) rumah tangga dipantau dan yang ber-PHBS 259155 atau 52,7\%. (Profil Kesehatan Kabupaten Banyumas Tahun 2015)

Berbagai faktor yang menghambat masyarakat menjalankan perilaku hidup bersih dan sehat antara lain adalah meliputi pendidikan dan pengetahuan terhadap PHBS. Masing-masing faktor ini saling berinteraksi dan pengaruh terhadap fase akhir, yaitu praktik PHBS. (Anies, 2006).

Berdasarkan latar belakang di atas, maka penelitian ini memilih Desa Banjasari Kulon, Kecamatan Sumbang, Kabupaten Banyumas karena masih didapati beberapa hal yang mempengaruhi rendahnya PHBS dibandingkan di desa lainnya, diantaranya ditemukan beberapa warga yang belum melaksanakan perilaku hidup bersih dan sehat tatanan rumah tangga di rumah, seperti pada kelompok KIA dan gizi masih ditemui indikator yang masih belum memenuhi syarat, yaitu terdapat 683 KK yang belum melakukan persalinan dengan ditolong oleh tenaga kesehatan, terdapat $939 \mathrm{KK}$ yang belum memberikan ASI eksklusif kepada bayi mereka, dan 689 KK yang tidak menimbang balita mereka secara rutin, kemudian pada kelompok Kesling masih ditemui indikator yang belum memenuhi syarat, yaitu terdapat $444 \mathrm{KK}$ yang belum menggunakan jamban untuk membuang air besar dan terdapat $102 \mathrm{KK}$ yang lantai rumahnya belum terbuat dari keramik dan masih berupa tanah, dan pada kelompok gaya hidup, masih terdapat beberapa indikator yang belum memenuhi syarat, yaitu terdapat $656 \mathrm{KK}$ yang memiliki kebiasaan merokok di dalam rumah (Rekapitulasi Hasil Pengkajian PHBS Tatanan Rumah Tangga Puskesmas 2 Sumbang Tahun 2016). 
Berdasarkan uraian di atas, peneliti tertarik untuk melakukan penelitian di Desa Banjarsari Kulon dengan judul "Hubungan Tingkat Pengetahuan dengan Perilaku Hidup Bersih dan Sehat (PHBS) Rumah Tangga di Desa Banjarsari Kulon Kabupaten Banyumas Tahun 2017”.

Permasalahan pada penelitian ini adalah apakah tingkat pengetahuan anggota rumah tangga berpengaruh dengan penerapan Perilaku Hidup Bersih dan Sehat (PHBS) rumah tangga di Desa Banjarsari Kulon Kabupaten Banyumas tahun 2017.

Tujuan penelitian ini adalah untuk mengetahui apakah ada hubungan antara tingkat pengetahuan dengan Perilaku Hidup Bersih dan Sehat (PHBS) Rumah Tangga di Desa Banjarsari Kulon Kabupaten Banyumas Tahun 2017.

\section{Bahan dan Metode}

Jenis penelitian ini adalah penelitian obsevasional analitik dengan pendekatan cross sectional yang bertujuan untuk mengetahui hubungan tingkat pengetahuan masyarakat terhadap perilaku hidup bersih dan sehat tatanan rumah tangga di Desa Banjarsari Kulon tahun 2017. Pengumpulan data dilakukan dengan cara wawancara, obeservasi, dan dokumentasi. Intrumen yang digunakan berupa checklist dan kuesioner.

\section{Hasil dan Pembahasan}

Berdasarkan hasil penelitian terhadap tingkat pengetahuan PHBS dan perilaku hidup bersih dan sehat (PHBS) rumah tangga yang telah dilaksanakan di Desa Banjarsari Kulon dapat dilihat pada hasil dan pembahasan sebagai berikut :

\section{a. Gambaran Umum Desa Banjarsari Kulon}

Letak Geografi Desa Banjarsari Kulon termasuk dalam wilayah Kecamatan Sumbang Kabupaten Banyumas yang terletak disebelah barat daya $\pm 5 \mathrm{~km}$ dari Kecamatan Sumbang, yang dapat ditempuh dalam waktu \pm 15 menit. Sampai saat ini belum ada transportasi umum yang menghubungkan langsung desa Banjarsari Kulon dari pusat kota Kabupaten Banyumas berjarak $\pm 9,5 \mathrm{~km}$ dan apabila ditempuh dengan menggunakan kendaraan pribadi memakan waktu \pm 25 menit. Desa Banjarsari Kulon terdiri atas 2 (dua) kepala dusun, 3 (tiga) RW, dan 17 (tujuh belas) RT. Sebelah utara Desa Banjarsari Kulon berbatasan dengan Desa Kotayasa, sebelah selatan berbatasan dengan Desa Datar dan Desa Karanggintung, sebelah timur berbatasan dengan Desa Banjarsari Wetan, dan sebelah barat berbatasan dengan Kecamatan Baturraden.

Sebagian besar wilayah desa Banjarsari Kulon adalah sawah dan terdapat sungai di desa Banjarsari Kulon. Rata-rata masyarakat di desa Banjarsari Kulon menggunakan Pamsimas sebagai sumber air bersih untuk memenuhi kebutuhan sehari-hari. Secara umum mata pencaharian masyarakat di desa Banjarsari Kulon adalah petani di ladang milik mereka sendiri, karena sebagian besar wilayah di desa Banjarsari Kulon adalah sawah. Selain petani, masyarakat di desa Banjarsari Kulon bermata pencaharian sebagai buruh tani, pedagang, tukang kayu, tukang batu, karyawan swasta, dll.

b. Karakteristik Responden

Sebagai upaya untuk mengetahui karekteristik responden di desa Banjarsari Kulon, maka dilakukan pengempulan data melalui kuesioner yang diikuti dengan wawancara dengan masyarakat desa Banjarsari Kulon. Berikut hasil pengumpulan data mengenai karakteristik responden yang terdiri dari umur dan pekerjaan responden.

1.) Umur

Distribusi responden berdasarkan umur dapat dilihat dalam tabel berikut :

Tabel 1. Distribusi Responden Berdasarkan Umur

\begin{tabular}{|c|c|c|}
\hline Umur & Frekuensi & $\begin{array}{c}\text { Persentase } \\
\% \\
\end{array}$ \\
\hline $\begin{array}{c}18-39 \text { tahun } \\
\text { (Dewasa Awal) }\end{array}$ & 47 & 67,142 \\
\hline $\begin{array}{c}40 \text { - } 60 \text { tahun } \\
\text { (Dewasa Madya) }\end{array}$ & 23 & 32,857 \\
\hline Jumlah & 70 & 100 \\
\hline
\end{tabular}
sebagian besar responden berusia 18 - 39 tahun yaitu sebanyak 47 orang dengan persentase sebanyak 67,142 \%, sedangkan responden yang berusia 40 - 60 tahun yaitu sebanyak 23 orang dengan persentase sebanyak 32,857\%.

Menurut Wawan dan Dewi (2011), usia adalah umur individu yang terhitung individu yang terhitung mulai saat dilahirkan sampai berulang tahun. Semakin cukup umur tingkat kematangan dan kekuatan seseorang akan lebih matang dalam berfikir dan bekerja, dari segi kepercayaan masyarakat seseorang yang dewasa dipercaya dari orang yang belum tinggi kedewasaannya. Hal ini akan sebagian dari pengalaman dan kematangan jiwa.

\section{2.) Pekerjaan}

Distribusi responden berdasarkan pekerjaan dapat dilihat dalam tabel berikut : 
Tabel 2. Distribusi Responden Berdasarkan Jenis Pekerjaan

\begin{tabular}{ccc}
\hline \hline Jenis Pekerjaan & Frekuensi & Persentase \% \\
\hline Pedagang & 7 & 10 \\
Buruh Tani & 9 & 12,857 \\
Guru TK & 1 & 1,428 \\
Pekerja Swasta & 1 & 1,428 \\
Pengrajin Bulu Mata & 1 & 1,428 \\
Ibu Rumah Tangga & 50 & 71,428 \\
\hline Jumlah & 70 & 100 \\
\hline
\end{tabular}

Berdasarkan tabel 2 dapat diketahui bahwa sebagian besar responden tidak bekerja atau sebagai ibu rumah tangga yaitu sebanyak 50 orang dengan persentase sebanyak $71,428 \%$, pedagang yaitu sebanyak 7 orang dengan persentase sebanyak $10 \%$, buruh tani yaitu sebanyak 9 orang dengan persentase sebanyak $12,857 \%$, ibu rumah tangga yaitu sebanyak 50 orang dengan persentase sebanyak $71,428 \%$, guru TK yaitu sebanyak 1 orang dengan persentase sebanyak 1,428 \%, pekerja swasta yaitu sebanyak 1 orang dengan persentase sebanyak $1,428 \%$, dan pengrajin bulu mata yaitu sebanyak 1 orang dengan persentase sebanyak $1,428 \%$.

Menurut Wawan dan Dewi (2010), pekerjaan adalah keburukan yang harus dilakukan terutama untuk menunjang kehidupannya dan kehidupan keluarga. Pekerjaan bukanlah sumber kesenangan, tetapi lebih banyak merupakan cara mencari nafkah yang membosankan , berulang dan banyak tantangan. Sedangkan bekerja umumnya merupakan kegiatan menyita waktu.

c. Pengetahuan PHBS Rumah Tangga Masyarakat Desa Banjarsari Kulon

Rekapitulasi responden berdasarkan tingkat pengetahuan dapat dilihat dalam tabel berikut :

Tabel 3. Rekapitulasi Responden Berdasarkan Tingkat Pengetahuan

\begin{tabular}{|c|c|c|c|}
\hline \multirow{2}{*}{ NO. } & \multirow{2}{*}{ Pertanyaan } & \multicolumn{2}{|c|}{$\begin{array}{c}\text { Rerata Jawaban } \\
\text { Benar }\end{array}$} \\
\hline & & Jumlah & $\begin{array}{c}\text { Persentase } \\
\%\end{array}$ \\
\hline 1. & $\begin{array}{lll}\text { Kelompok KIA dan } \\
\text { Gizi }\end{array}$ & 66,6 & $95,12 \%$ \\
\hline 2. & $\begin{array}{c}\text { Kelompok } \\
\text { Kesehatan Lingkungan }\end{array}$ & 64,2 & $91,68 \%$ \\
\hline 3. & Kelompok Gaya Hidup & 59,4 & $84,8 \%$ \\
\hline 4. & $\begin{array}{ll}\text { Kelompok } & \text { Upaya } \\
\text { Kesehatan Masyarakat }\end{array}$ & 84,8 & $88,24 \%$ \\
\hline
\end{tabular}

Berdasarkan tabel 3 dapat diketahui bahwa ratarata pengetahuan responden tentang PHBS untuk kelompok KIA dan gizi diperoleh rata-rata 66,6 dengan persentase 95,12 \%, untuk kelompok kesehatan lingkungan diperoleh rata-rata 64,2 dengan persentase $91,68 \%$, untuk kelompok gaya hidup diperoleh rata-rata
59,4 dengan persentase 84,8 \%, dan untuk kelompok upaya kesehatan masyarakat diperoleh rata-rata 61,8 dengan persentase $88,24 \%$.

Tabel 4. Rekapitulasi Pengetahuan Responden tentang PHBS

\begin{tabular}{|c|c|c|}
\hline $\begin{array}{c}\text { Tingkat } \\
\text { Pengetahuan }\end{array}$ & Frekuensi & Persentase \% \\
\hline Baik & 66 & 94,285 \\
\hline Sedang & 3 & 4,285 \\
\hline Kurang & 1 & 1,428 \\
\hline Jumlah & 70 & 100 \\
\hline $\begin{array}{l}\text { Berdasarkan } \\
\text { tingkat pengetahuan } \\
\text { tergolong baik ya } \\
\text { persentase sebanyal } \\
\text { dengan tingkat pen } \\
\text { orang dengan persen } \\
\text { tingkat pengetahuan } \\
\text { persentase sebanyak }\end{array}$ & $\begin{array}{l}\text { el } 4 \text { dapat } \\
\text { onden di des } \\
\text { sebanyak } 6 \\
\text {,285 \%, sed } \\
\text { huan sedang } \\
\text { 4,285\% dan } \\
\text { ang sebanya }\end{array}$ & $\begin{array}{l}\text { diketahui bahwi } \\
\text { Banjarsari Kuloı } \\
6 \text { orang dengaı } \\
\text { angkan respondeı } \\
\text { yaitu sebanyak } \\
\text { responden dengar } \\
\text { k } 1 \text { orang dengaı }\end{array}$ \\
\hline
\end{tabular}

d. Sikap PHBS Rumah Tangga Desa Masyarakat Banjarsari Kulon

Rekapitulasi responden berdasarkan sikap PHBS dapat dilihat dalam tabel berikut :

Tabel 5. Rekapitulasi Responden tentang Sikap PHBS

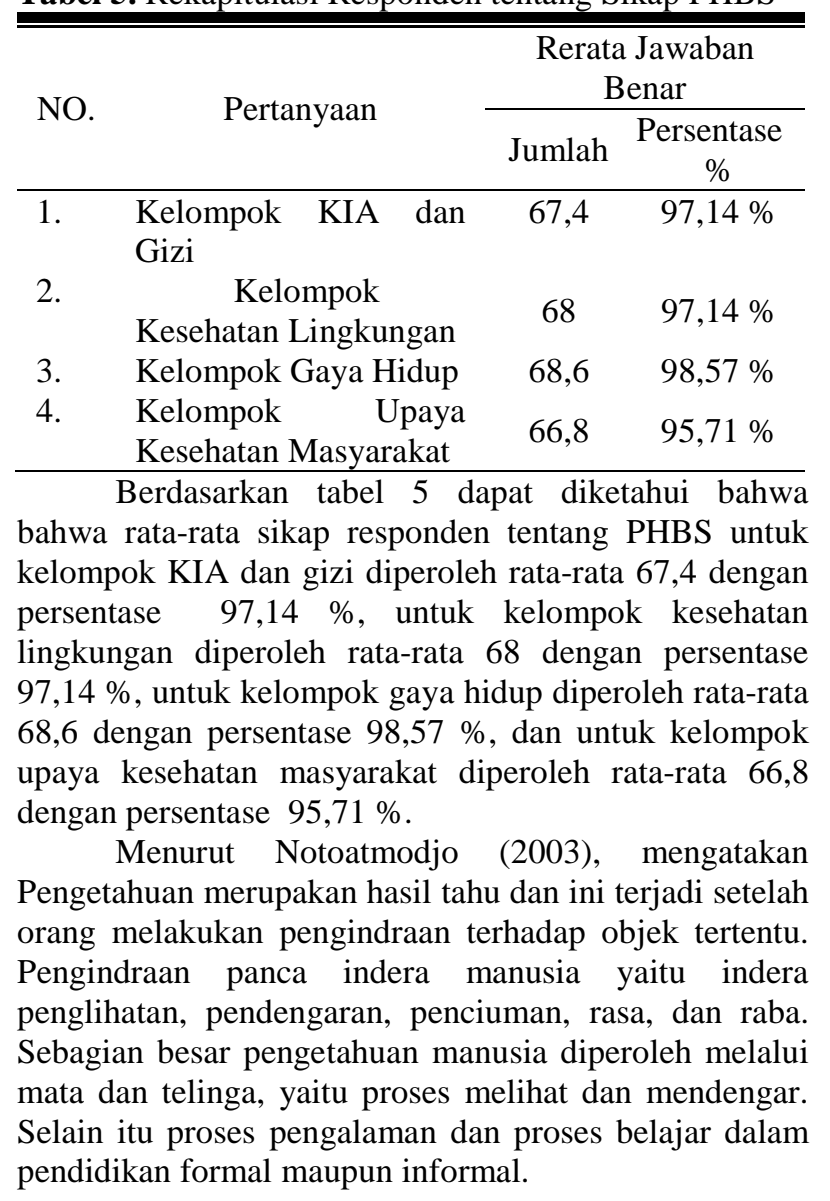


Pengetahuan itu sendiri dipengaruhi oleh faktor pendidikan formal. Pengetahuan sangat erat hubungannya dengan pendidikan, dimana diharapkan bahwa dengan pendidikan yang tinggi maka orang tersebut akan semakin luas pula pengetahuannya. Akan tetapi perlu ditekankan, bukan berarti seseorang yang berpendidikan rendah mutlak berpengetahuan rendah pula. Hal ini mengingat bahwa peningkatan pengetahuan tidak mutlak diperoleh dari pendidikan formal saja, akan tetapi dapat diperoleh melalui pendidikan non formal. Pengetahuan seseorang tentang suatu obyek mengandung dua aspek, yaitu aspek positif dan aspek negatif. Kedua aspek ini yang akan menentukan sikap seseorang. Semakin banyak aspek positif dan objek yang diketahui, maka akan menimbulkan sikap makin positif terhadap objek tertentu. Menurut WHO (World Health Organization), salah satu bentuk objek kesehatan dapat dijabarkan oleh pengetahuan yang diperoleh dari pengalaman sendiri (Wawan, A dan Dewi M, 2010).

Pengukuran pengetahuan penulis menggunakan pengkategorian menurut Machfoedz (2009) yaitu:

a. Baik, bila subjek mampu menjawab dengan benar 76$100 \%$ dari seluruh pernyataan.

b. Cukup, bila subjek mampu menjawab dengan benar 56-75\% dari seluruh pernyataan.

c. Kurang, bila subjek mampu menjawab dengan benar $<56 \%$ dari seluruh pernyataan.

Tabel 6. Distribusi Sikap Responden tentang PHBS

\begin{tabular}{ccc}
\hline \hline Sikap & Frekuensi & Persentase \% \\
\hline Baik & 70 & 100 \\
Sedang & - & 0 \\
Kurang & - & 0 \\
\hline Jumlah & 70 & 100 \\
\hline
\end{tabular}

Berdasarkan tabel 6 dapat diketahui bahwa responden dengan sikap PHBS baik yaitu sebanyak 70 orang dengan persentase sebanyak $100 \%$.

Menurut Notoatmodjo (2010), mendefinisikan pengertian sikap dengan sangat sederhana bahwa sikap itu suatu sindrom atau kumpulan gejala dalam merespons stimulus atau objek. Sehingga sikap itu melibatkan pikiran, perasaan, perhatian, dan gejala kewajiban yang lain.

Menurut Thomas dan Znaniecki (1920) yang dikutip Wawan, A dan Dewi. M (2010), menegaskan bahwa sikap adalah predisposisi untuk melakukan atau tidak melakukan suatu perilaku tertentu, sehingga sikap bukan hanya kondisi internal psikologis yang murni dari individu (purely physic inner state), tetapi sikap lebih merupakan proses kesadaran yang sifatnya individual. Artinya, proses ini terjadi secara subyektif dan unik pada diri setiap individu. Keunikan ini dapat terjadi oleh adanya perbedaan individual yang berasal dari nilai-nilai dan norma yang ingin dipertahankan dan dikelola oleh individu.
Sikap secara nyata menunjukkan konotasi adanya kesesuaian reaksi terhadap stimulus tertentu yang dalam kehidupan sehari-hari merupakan reaksi yang bersifat emosional terhadap stimulus sosial.

e. PHBS Rumah Tangga Desa Masyarakat Banjarsari Kulon

Rekapitulasi responden berdasarkan PHBS dapat dilihat dalam tabel berikut :

Tabel 7. Rekapitulasi Responden tentang PHBS

\begin{tabular}{|c|c|c|c|}
\hline \multirow{2}{*}{ NO. } & \multirow{2}{*}{ Pertanyaan } & \multicolumn{2}{|c|}{$\begin{array}{c}\text { Rerata Jawaban } \\
\text { Benar } \\
\end{array}$} \\
\hline & & Jumlah & $\begin{array}{c}\text { Persentase } \\
\%\end{array}$ \\
\hline 1. & $\begin{array}{l}\text { Kelompok KIA dan } \\
\text { Gizi }\end{array}$ & 67,4 & $96,24 \%$ \\
\hline 2. & $\begin{array}{c}\text { Kelompok } \\
\text { Kesehatan Lingkungan }\end{array}$ & 61 & $87,12 \%$ \\
\hline 3. & Kelompok Gaya Hidup & 55 & $78,54 \%$ \\
\hline 4. & $\begin{array}{l}\text { Kelompok Upaya } \\
\text { Kesehatan Masyarakat }\end{array}$ & 47,6 & $67,96 \%$ \\
\hline
\end{tabular}

Berdasarkan tabel 7 dapat diketahui bahwa bahwa rata-rata praktik responden tentang PHBS untuk kelompok KIA dan gizi diperoleh rata-rata 67,4 dengan persentase 96,24 \%, untuk kelompok kesehatan lingkungan diperoleh rata-rata 61 dengan persentase $87,12 \%$, untuk kelompok gaya hidup diperoleh rata-rata 55 dengan persentase 78,54 \%, dan untuk kelompok upaya kesehatan masyarakat diperoleh rata-rata 47,6 dengan persentase $67,96 \%$.

Tabel 8. Distribusi Responden Berdasarkan PHBS

\begin{tabular}{ccc}
\hline \hline Praktik & Frekuensi & Persentase \% \\
\hline Baik & 63 & 90 \\
Sedang & 7 & 10 \\
Kurang & - & 0 \\
\hline Jumlah & 70 & 100 \\
\hline
\end{tabular}

Berdasarkan tabel 8 dapat diketahui bahwa responden dengan PHBS baik yaitu sebanyak 63 orang dengan persentase sebanyak $90 \%$, sedangkan responden dengan praktik PHBS sedang sebanyak 7 orang dengan persentase sebanyak $10 \%$.

Suatu sikap belum otomatis terwujud dalam suatu tindakan (overt behaviour). Untuk mewujudkan sikap menjadi suatu perbuatan nyata diperlukan faktor pendukung atau suatu kondisi yang memungkinkan, antara lain adalah fasilitas. Di samping faktor fasilitas, juga diperlukan faktor dukungan (support) dari pihak lain, misalnya dari suami atau istri, orang tua atau mertua, dan lain-lain. Praktik ini mempunyai beberapa tingkatan, antara lain : a.) Persepsi, b.) Respon terpimpin, c.) Mekanisme, d.) Adopsi.

Pengukuran perilaku dapat dilakukan secara tidak langsung yakni dengan wawancara terhadap kegiatankegiatan yang telah dilakukan beberapa jam, hari, atau bulan yang lalu (recall). Pengukuran juga dapat 
dilakukan secara langsung, yakni dengan mengobservasi tindakan atau kegiatan responden. (Notoadmodjo, 2007, Promosi Kesehatan \& Ilmu Perilaku).

f. Uji Statistik Hubungan Tingkat Pengetahuan PHBS Rumah Tangga dengan PHBS

Analisis bivariat yang dilakukan pada dua variabel yaitu tingkat pengetahuan PHBS dengan PHBS di Desa Banjarsari Kulon, Kecamatan Sumbang, Kabupaten Banyumas. Anallisis data dalam penelitian ini menggunakan Pearson Product Moment dengan program SPSS dapat dilihat pada tabel berikut :

Tabel 9. Analisis Hasil Hubungan Tingkat Pengetahuan dengan PHBS

\begin{tabular}{lcc}
\hline \hline & Korelasi & $\begin{array}{c}\text { Signifikansi } \\
\mathbf{P}(\mathbf{0 , 0 0 0 )}\end{array}$ \\
\hline Pengetahuan & 1 & $.421^{* *}$ \\
PHBS & $.421^{* *}$ & 1 \\
\hline \multicolumn{1}{c}{ Berdasarkan } & tabel 9 di atas dapat diketahui
\end{tabular}
bahwa ada hubungan antara tingkat pengetahuan dengan PHBS. Hasil penelitian menunjukkan tingkat pengetahuan baik sebanyak 66 responden (94,285\%), tingkat pengetahuan sedang sebanyak 3 responden $(4,285 \%)$, sedangkan responden dengan tingkat pengetahuan kurang sebanyak 1 responden $(1,428 \%)$ dan PHBS baik yaitu sebanyak 63 responden (90\%), sedangkan responden dengan PHBS sedang sebanyak 7 responden $(10 \%)$.

Disini dijelaskan bahwa ada hubungan positif antara tingkat pengetahuan responden dengan PHBS rumah tangga. Ditunjukkan dengan signifikan 0,000 dengan arah hubungan positif sebesar 0,421 sehingga menunjukkan adanya hubungan antara tingkat pengetahuan dengan PHBS rumah tangga.

Hasil analisis Pearson Product Moment dengan signifikan 0,000 sehingga dikatakan bahwa ada hubungan positif antara tingkat pengetahuan responden dengan praktik PHBS rumah tangga. Ditunjukkan dengan signifikan 0,000 dengan arah hubungan positif sebesar 0,421 sehingga menunjukkan adanya hubungan antara tingkat pengetahuan dengan praktik PHBS rumah tangga di Desa Banjarsari Kulon, Kecamatan Sumbang, Kabupaten Banyumas.

\section{Kesimpulan}

Berdasarkan hasil penelitian tentang hubungan antara tingkat pengetahuan dengan perilaku hidup bersih dan sehat (PHBS) rumah tangga di desa Banjarsari Kulon, Kecamatan Sumbang, Kabupaten Banyumas, dapat disimpulkan sebagai berikut :

a. Tingkat pengetahuan responden tentang PHBS mayoritas termasuk dalam kategori baik, yaitu sebanyak 66 orang dengan persentase sebanyak 94,285\%, sedangkan responden dengan tingkat pengetahuan sedang yaitu sebanyak 3 orang dengan persentase 4,285
$\%$ dan responden dengan tingkat pengetahuan kurang sebanyak 1 orang dengan persentase sebanyak 1,428 \%. b. Perilaku Hidup Bersih dan Sehat (PHBS) rumah tangga masyarakat Desa Banjarsari Kulon tergolong cukup baik, namun masih terdapat warga yang belum menerapkan PHBS. Pada kelompok kesehatan lingkungan, masih ditemui warga yang belum memiliki jamban dan septictank, belum melakukan pengelolaan sampah dengan baik, dan lantai rumah belum terbuat dari keramik. Pada kelompok gaya hidup, masih ditemui warga yang belum melakukan aktifitas fisik setiap hari dan memiliki kebiasaan merokok di dalam dan di luar rumah. Dan pada kelompok upaya kesehaatan masyarakat, masih ditemui warga yang belum menjadi anggota Jaminan Pemeliharaan Kesehatan (JPK).

c.Perilaku Hidup Bersih dan Sehat (PHBS) responden mayoritas termasuk dalam kategori baik, yaitu sebanyak sebanyak 63 orang dengan persentase sebanyak $90 \%$, sedangkan responden dengan praktik PHBS sedang sebanyak 7 orang dengan persentase sebanyak $10 \%$.

d. Ada hubungan antara tingkat pengetahuan dengan PHBS di Desa Banjarsari Kulon, Kecamatan Sumbang, Kabupaten Banyumas, yaitu ada hubungan positif antara tingkat pengetahuan responden dengan praktik PHBS rumah tangga. Ditunjukkan dengan signifikan 0,000 dengan arah hubungan positif sebesar 0,421 sehingga menunjukkan adanya hubungan antara tingkat pengetahuan dengan praktik PHBS rumah tangga.

Disarankan untuk permasalahan perilaku hidup bersih dan sehat (PHBS) di Desa Banjarsari Kulon dapat dilakukan upaya sebagai berikut :

a. Sanitarian Puskesmas 2 Sumbang : Perlunya peningkatan penyuluhan minimal sebulan sekali dengan memberikan edukasi tentang pentingnya menerapkan perilaku hidup bersih dan sehat (PHBS) di rumah tangga pada seluruh masyarakat melalui kader-kader kesehatan maupun pada saat kegiatan perkumpulan warga desa.

b. Kepala Desa : Mengadakan septictank komunal yang letaknya terjangkau oleh kendaraan yang dapat menyedot kotoran (tinja) bagi warga yang belum memiliki sepetictank di rumah. Sehingga warga tidak lagi mengalirkan kotoran dari jamban ke sungai di dekat rumah warga.

c. Kepala Keluarga : Dapat menggerakkan anggota keluarga untuk melakukan praktik tentang perilaku hidup bersih dan sehat (PHBS) di rumah tangga pada seluruh anggota keluarga di rumah.

\section{Ucapan Terima Kasih}

Terima kasih disampaikan kepada masyarakat Desa Banjarsari Kulon, Kecamatan Sumbang, yang telah memberikan ijin untuk melakukan penelitian di Desa Banjarsari Kulon serta seluruh pihak yang telah membantu dalam penyelesaian penelitian. 


\section{Daftar Pustaka}

Akmal Taher, dkk, 2016, Pedoman Umum Program Indonesia Sehat dengan Pendekatan Keluarga, Kementerian Kesehatan RI : Jakarta

Cahyono Tri, 2014, Pedoman Penulisan Proposal Penelitian dan Karya Tulis Ilmiah / Skripsi (Edisi Revisi Ketiga), Poltekkes Kementerian Kesehatan Semarang : Semarang

Departemen Kesehatan, 2009, Pedoman Pembinaan dan Pelatihan Perilaku Hidup Bersih dan Sehat (PHBS) di Rumah Tangga melalui Tim Penggerak PKK, Departemen Kesehatan RI : Jakarta

Desa Banjarsari Kulon Kecamatan Sumbang Pemerintah Kabupaten Banyumas, 2017, Wilayah Desa Banjarsari Kulon, at http://banjarsarikulon.sumbang kec.banyumaskab.go.id/page/7261/wilayah-desa\#. WT90JtzFnVo diakses pada Selasa, 13 Juni 2017 pukul 12:19 WIB

Dinas Kesehatan Kabupaten Banyumas, 2015, Profil Kesehatan Kabupaten Banyumas Tahun 2015, Dinas Kesehatan Kabupaten Banyumas : Banyumas

Dinas Kesehatan Provinsi Jawa Tengah, 2015, Profil Kesehatan Provinsi Jawa Tengah Tahun 2015, at www.dinkesjatengprov.go.id diakses pada 26 Januari 2017 pukul 10:54 WIB

Dragonity, 2011, Perilaku Hidup Bersih dan Sehat (PHBS), at http://blogkesmas.blogspot .co.id /2011/ 11/perilaku-hidup-bersih-dan-sehat-phbs.html diakses pada 26 Januari 2017 pukul 10:58 WIB

Dyah Ayu Anggraini, 2013, Perilaku Hidup Bersih dan Sehat (PHBS), at http://ayuanggrainidyah.blogspot .co.id/2013/10/perilaku-hidup-bersih-dan-sehatphbs.html diakses pada 26 Januari 2017 pukul 11:05 WIB

Elentawang Rose, 2015, Perilaku Hidup Bersih dan Sehat (PHBS), at http://elentawang.blogspot.co.id /2015_04_01_archive.html diakses pada 26 Januari 2017 pukul 11:08 WIB

Erwin Ramadhani Pratama Putra, 2013, Visi Misi Indonesia Sehat 2015, at http://nersputerasampoerna. blogspot.co.id/2013/01/visi-misi-indonesia-sehat2015.html_diakses pada 26 Januari 2017 pukul 11:17 WIB
Hartono Bambang, 2010, Promosi Kesehatan di Puskesmas dan Rumah Sakit, Rineka Cipta : Jakarta

Hasni Hidayatul, 2012, Hubungan Pengetahuan dan Tingkat Pendidikan Kepala Keluarga Terhadap Perilaku Hidup Bersih dan Sehat Keluarga di Kelurahan Limau Manis Selatan Tahun 2012

Lestari Titik, 2015, Kumpulan Teori Untuk Kajian Pustaka Penelitian Kesehatan, Nuha Medika : Yogyakarta

Notoatmodjo Soekidjo. 2013. Promosi Kesehatan Global, Rineka Cipta : Jakarta

Notoatmodjo Soekidjo, 2010, Promosi Kesehatan Teori \& Aplikasi, Rineka Cipta : Jakarta

Notoatmodjo Soekidjo, 2013, Ilmu Perilaku Kesehatan, Rineka Cipta : Jakarta

Notoatmodjo Soekidjo, 2010, Promosi Kesehatan \& Ilmu Perilaku, Rineka Cipta : Jakarta

Nurjanah Putri, 2013, Tingkat Pengetahuan Ibu Rumah Tangga tentang Perilaku Hidup Bersih dan Sehat (PHBS) di Desa Keden Wetan Kelurahan Keden Kecamatan Kalijambe Kabupaten Sragen Tahun 2013

Pamungkas Adi Rian, 2016, Statistik Untuk Perawat dan Kesehatan Dilengkapi Tutorial SPSS dan Interpretasi Data, CV. Trans Info Media : Jakarta 